\title{
The Physiological Effects on Some Traits of Osmopriming Germination of Maize (Zea mays L.), Rice (Oryza sativa L.) and Cucumber (Cucumis sativus L.)
}

\author{
Reza Rezaei Sokht-Abandani (Corresponding author) \& Mehdi Ramezani \\ Yung Researcher Club Member Talent, Department of Agronomy \\ Science and Research Branch, Islamic Azad University, Tehran, Iran \\ E-mail: Rezaei9533@yahoo.com
}

$\begin{array}{lc}\text { Received: January 11, } 2012 & \text { Accepted: February 3, } 2012 \quad \text { Published: April 1, } 2012 \\ \text { doi:10.5539/ijb.v4n2p132 } & \text { URL: http://dx.doi.org/10.5539/ijb.v4n2p132 }\end{array}$

\begin{abstract}
To investigate the effects priming osmotic on seed germination of maize, two vessels SC 704, rice (Variety Neda) and cucumber (cultivar P.S), an experiment in a factorial design in randomized complete block with three replicates in the laboratory of Department of Agriculture, University vice of the city in 2011 was conducted. Treatments priming seed Soluble polyethylene glycol (PEG 6000) concentrations of 5 and 10 per cent, potassium nitrate $(\mathrm{KNO} 3)$ with concentrations of 1 and 2 percent potassium chloride $(\mathrm{KCl})$ concentrations of 2 and $4 \%$ and the duration of different plants, respectively (maize: 8, 16 and 24), (rice: 4, 8 and 12) and (cucumber: 6,12 and 18) had time. Traits measured included primary root and shoot length, germination rate and percent, primary root and shoot fresh weight, primary root dry weight, primary root/primary shoot fresh and dry weight proportion (R/S), primary root/primary shoot lenght proportion $(\mathrm{R} / \mathrm{S})$, the normal and abnormal seedlings number were Vigor 1 and 2 index. Results showed that root and shoot length for seed maize, rice and cucumber under treatment duration and concentration of the Prime Osmopriming respectively by polyethylene glycol (PEG), chloride and potassium nitrate $(\mathrm{KNO} 3$ and $\mathrm{KCl})$ concentrations of 5, 10, 2, 4 and 2 percent of the time 16, 8 and 12 hours respectively. The highest primary root/primary shoot lenght proportion $(\mathrm{R} / \mathrm{S})$ for seed maize, rice and cucumber treated with polyethylene glycol (PEG) and potassium nitrate (KNO3) with concentrations of 5, 10 and $1 \%$ during the period of 24,8 and $6 \mathrm{~h}$ was observed. The maximum primary root dry weight, primary root/primary shoot fresh weight proportion $(\mathrm{R} / \mathrm{S})$ for seed maize, cucumber and rice respectively by Prime Osmopriming nitrate and potassium chloride solution (KNO3 and $\mathrm{KCl}$ ) concentrations 1, 2 and 4 percent in the period 24, 8 and 6 hours was the result. More than how to primary root dry weight, primary root/primary shoot dry weight proportion $(\mathrm{R} / \mathrm{S})$ for rice and cucumber seeds, respectively, with the Prime solution of potassium nitrate (KNO3) concentration of 1 and 2 percent was achieved. The highest seed germination for maize, cucumber and rice under treatment duration and concentration of Osmopriming respectively by Prime soluble polyethylene glycol (PEG) and potassium chloride $(\mathrm{KCl})$ concentrations of 5, 2 and 4 percent during the time periods were 24 and 12 hours. The maximum percentage of germination for seeds of rice and cucumber, respectively, during the period of 4 and $6 \mathrm{~h}$ were achieved. While most of the seed maize and cucumber root fresh weight, respectively by the Prime Solution Osmopriming polyethylene glycol (PEG) and potassium nitrate (KNO3) with concentrations of 5 and 2 percent during the period 16, 24 and 18 hours respectively. Most of the seed rice Vigor a period of 8 hours was the minimum index Vigor 2 treatments and the concentration of Osmopriming term treatment with potassium chloride $(\mathrm{KCl})$ concentration of $4 \%$ during the period of 12 hours was achieved. The best treatment for this research to plant maize, rice and cucumber respectively by Prime Solution Polyethylene glycol and potassium chloride concentrations of 5 and $4 \%$ better germination and seedling growth in Compared to other solutions have been proposed.
\end{abstract}

Keywords: Maize, Rice and Cucumber, Osmopriming, Germination Rate and Percent, Vigor 1 and 2 index

\section{Introduction}

According to the food and Agriculture Organization of the most important crop is maize, and in 2007 the grain and seed production in the world respectively, 791.8 and 5.6 million tonnes is and this plant and the production of wheat and rice in the third (FAO, 2007). Iran's share in the production of maize in 2010 crop of 265,007 acres under cultivation, 2,010,318 tons of corn grain yield was.7423.42 $\mathrm{kg}$ per hectare producti (Anonymous, 2010). 
Rice is the world's second most important cereal in Iran is of particular importance, So that much of the food, especially in the provinces of, Mazandaran and Guilan make up. According to available statistics, due to increased population, increased consumption of rice, so that the product does not meet consumer and inevitably a considerable amount of rice imported from abroad, this deficiency can be compensated (Khodabandeh, 1992). Since the majority of rice the native feet high, fertilizer management low susceptibility to diseases and lodging, function are low, hence the need for imports and foreign ownership will increase in coming years more. Increase population and the increasing need for human food production, resource limitations on the one hand and the expression is the only way to achieve greater productivity, increased yield per unit area is through the production and use new and high-yielding hybrid rice varieties, and most recently with the procedures appropriate to the crop is possible (Dorosti, 2000). Cucumber from the kitchen garden products is important for germination in early spring, they play a crucial role in the rapid deployment of plant and production is premature. For this purpose, the relative kitchen garden the seeds soaked in water will one day ahead. The slow and uniform germination at low temperatures in addition to the farm operations makes it difficult, Seedlings are more susceptible to diseases of the terrestrial and the doubly reduced product will follow (Aliabadi and Lotfi, 2008). Priming strategy is needed in order to be able to enhance germination and maize establishment the use of soil moisture, solar radiation and provide for the plant. In this case, the plant would be able early fall before the stresses of their growing period completed (Subedi and Ma, 2005). Research results indicate that since the use of treatments to increase seed germination and early vigor, emerging uniform and the strong plants achieved (Afzal et al., 2002; Ashraf and Foolad, 2005; Farooq et al., 2006). The main purpose priming seeds, improving seed performance under specific environmental conditions. Priming pract applications, including increasing the percentage of germination, Under certain environmental conditions improve germination and seedling vigor and growth is (Parera and Cantiffe, 1994). Before sowing seed treatments can be various methods such as Hydropriming (soaked in water), Osmopriming (soaking in osmotic solutions) and the use of growth regulators or solid material used (Pizzeghello et al., 2001). Priming salts or polyethylene glycol is often the seed for faster germination, seed germination and uniform emergence, especially in adverse environmental conditions in some of the vegetables used (Nascimento, 2003). Subedi and Ma (2005) watermelon tolerance to salinity, but also increased in the early stages of growth. Chojnowski and Come (1997) The effects of different materials priming on the germination of watermelon Demir and Mavi (2004) also Osmopriming effects ( $2 \%$ potassium nitrate solution for 6 days at $20^{\circ} \mathrm{C}$ ) and hydropriming (distilled water at $30^{\circ} \mathrm{C}$ for 18 days) Watermelon seeds planted at three temperatures 15,25 and $38^{\circ} \mathrm{C}$ were studied and reported at 25 and $38^{\circ} \mathrm{C}$ View Post hydropriming effect on germination and seed is not. The purpose of this experiment, the effect of SC 704 Maize Priming seeds of two vessels, Rice cultivars Neda and cucumber varieties (P.S) on seed germination and seedling vigor in some qualitative properties of optimal utilization of water resources and soil and also to determine the best time for planting the seed priming.

\section{Materials and Methods}

In order to study the effects of osmopriming on germination SC. 704 maize, rice cultivars Neda and cucumber, a factorial experiment in completely randomized design with three replications in the laboratory, Faculty of Agriculture, Islamic Azad University vice city in 2011 was conducted. Treatments priming seed solution polyethylene glycol (PEG 6000) concentrations of 5 and 10 percent, potassium nitrate (KNO3) with concentrations of 1 and 2 percent and potassium chloride $(\mathrm{KCl})$ concentration and duration of 2 and $4 \%$ respectively of different plants (maize, 8, 16 and 24), (Rice: 4, 8 and 12) and (cucumber: 6,12 and 18) had the time. Use of seeds and Plant Improvement Institute seeds was prepared. After the desired period priming, seeds and all seeds priming by washing with distilled water until the initial weight at room temperature and dark conditions were dry. To assess germination, 25 seeds from each treatment within the Petri glass (diameter $90 \mathrm{~mm}$ ) between two layers of filter paper were placed in $10 \mathrm{ml}$ of distilled water to the Petri dishes were added to the germination grown with temperature of $25 \pm 2^{\circ} \mathrm{C}$ (ISTA, 2008) with $42 \%$ relative humidity and were transferred to dark. The root length of $2 \mathrm{~mm}$ considered as seed germination and the seeds germinated at day 7 and 8 in each treatment were counted and root length, shoot and seedling, root and shoot fresh weight and dry weight of root. Although the exact scale were measured with an accuracy of 0.001 grams. The primary root dry weight, primary root/primary shoot fresh and dry weight proportion $(\mathrm{R} / \mathrm{S})$ and the number of normal seedlings germinated and seedlings were also calculated. To calculate the germination rate and percent and index of the relation Vigor 1 and 2 below were used (Maguire, 1962, Bewley and Black, 1998, Nichols and Heydecker, 1968 and Kim and Kang, 1987):

Relation (1): percent germination $=($ total number of seeds $/$ number of germinated seeds to the seventh and eighth day) $\times 100$ 
Relation (2): Germination rate:

$$
G R=\sum \frac{N i}{T i}
$$

Relation (3): Vigor index $(1)=$ percent germination $\times(\mathrm{mm})$ seedling height between 3

Relation (4): Vigor index (2) = percent germination $\times(\mathrm{g})$ dry weight of about 4

The data obtained by MSTAT-C statistical software for analysis and multi-domain mean comparisons Duncan's test at 5\% level was graphs were plotted by the Excel software.

\section{Results and Discussion}

\subsection{Primary roots and shoots length}

The primary roots length of maize, rice and cucumber significantly influenced by the concentration osmopriming solutions and their interaction on the level 1 error was 5\% (Table 1, 3 and 5). Comparison the interaction showed that the average root length for maize, rice and cucumber, respectively osmopriming PEG and treated in time $\mathrm{KCl}$ 24, 8 and $12 \mathrm{~h}$ with concentrations of 5, 10 and 4\% and the minimum in osmopriming treatment $\mathrm{KNO} 3, \mathrm{KCl}$ and PEG during the 8, 4 and 6 hours respectively, with concentrations of 1, 2, 10 and 2\% were obtained (Table 2, 4 and 6). Mohseni et al., (2010) concluded that at least on the two hybrid maize primary roots length for the treatments of potassium chloride and potassium nitrate at a concentration of 4 and $2 \%$ respectively $(0.813$ and 0.996$)$ Was the highest during the Priming respectively for treatments with polyethylene glycol (PEG) with a concentration of 5\% potassium chloride $(\mathrm{KCl})$ with $2 \%$ concentration, and water control was obtained. Sanchez et al., (2001) also reported that the seed length of the cucumber and pepper hydropriming significantly increased. Ghavami et al., (2004) analysis of salt stress on root and shoot of wheat cultivars stated that reducing the osmotic potential of root and shoot decreased. In the study by Rezaei and Ramezani (2010) on the rice plant was concluded that the maximum and minimum primary shoots length 8 and 12 hours respectively during 6.30 and 5.03 mm, respectively, the lowest shoot length, respectively, by the Prime KCl concentration of 2\% was obtained. Karaki (1998) Effect of polyethylene glycol concentration on the germination of wheat and barley will be seen that the root length decreased with decreasing water potential. Also Kaurs et al., (2002) showed that the production of hydrocarbons and osmopriming on peas seedlings with roots, stems and seeds priming not be larger than the amount of amylase activity in the stem priming seedlings is higher. Rezaei and Ramezani (2010) on cucumber plants expressed the rootlet length of time with 12 hours (7.100) and at least 6 hours (5.920) was obtained and the maximum and minimum lengths, respectively, with $\mathrm{KCl} 4$ rootlet \%, and PEG 10\% was achieved. Rezaei et al., (2009) in an experiment on 640 maize hybrids with different concentrations Priming reported maximum root length, respectively, for the treatment of pre treatment with pure water $(19.24 \mathrm{~mm})$ and minimum root length, respectively, for treatments potassium nitrate and potassium chloride at a concentration equal to 2 and 4\% (9.04 and $8.48 \mathrm{~mm}$ ), respectively. Rezaei and Ramezani (2009) found that the maximum length of 704 on the corn root (16.69 $\mathrm{mm})$ osmopriming PEG treated at 24 hours and the minimum $(13.11 \mathrm{~mm})$ in the treatment osmopriming KNO3 in 8 hours concentrations of 5 and $1 \%$ respectively were obtained. Maximum root length and duration of interactions priming to plant maize, rice and cucumber respectively by Prime KNO3 and PEG concentrations of 5 and 2 percent and the lowest osmopriming KNO3 and PEG treated with concentrations of 1 and 10\% was (Figure 1).

In this regard, researchers have shown that the maximum primary roots length (16.69 mm) PEG treated Osmopriming 24 hours and the minimum $(13.11 \mathrm{~mm})$ in the treatment Osmopriming KNO3 in 8 hours, respectively, with concentrations of 5 and 1\% was obtained (Rezaei and Ramezani, 2009). Rezaei and Ramezani (2010) found that rice seeds in the test shoot under the most interaction with the Prime Time and priming respectively by 2 percent and the lowest concentration of potassium nitrate with a concentration of $10 \%$ polyethylene glycol is . In another experiment on cucumber seeds stated that the maximum primary roots length under the effect of duration and concentration Osmopriming respectively by the Prime PEG 5\% T6 and KNO3 2\% T18 was obtained (Rezaei and Ramezani, 2010). Some researchers stated that the maximum primary roots length under priming $\times$ time interactions with the potassium nitrate concentration of $2 \%$ was achieved during $12 \mathrm{~h}$ in the cucumber (Rezaei and Ramezani, 2010). Analysis of variance showed that shoot length for corn, rice and cucumber under the influence of statistical term, solution concentration and the concentration of Osmopriming located on level 1 and 5\% (Table 1, 3 and 5). So that maximum primary shoots length for corn, rice and cucumber, respectively, during 16, 24, 8 and 12 hours respectively by Prime Solution to PEG, KNO3 and $\mathrm{KCl}$ concentrations of 5, 2 and 4 percent were obtained (Table 2, 4 and 6). Mohseni et al., (2010) SC 704 Corn Hybrid and 640 in the second study reported that the highest primary shoots length $(12.27 \mathrm{~mm})$ and minimum primary shoots length $(0.496 \mathrm{~mm})$ respectively for the control treatments and potassium chloride concentration of $4 \%$, respectively. 
Zeinal et al., (2001) stated that in canola root sensitivity to salt stress of the shoot is over. Rezaei and Ramezani (2010) in a series of laboratory studies on cucumber plants expressed the maximum and minimum primary shoots length over time 8 and 12 hours respectively, 6.30 and $5.30 \mathrm{~mm}$, respectively, the lowest primary shoots length respectively by the Prime $\mathrm{KCl}$ concentration of $2 \%$ was obtained. Kafi and Goldani (2000) Effect of water potential on germination of wheat have concluded that the decrease in water potential caused by polyethylene glycol 6000 was caused to increase germination and growth characteristics, along root and shoot weight gain and loss. Rezaei et al., (2010) reported on their results on 640 maize plants with the highest shoot length for pre treatment with potassium nitrate concentration of one percent $(13.42 \mathrm{~mm}$ ) and lowest during the shoot for the treatment with potassium chloride and potassium nitrate concentrations of 4 and $2 \%$ respectively 5.70 and 6.58 mm, respectively. Rezaei et al., (2010) in studies on hybrid maize Priming 704 at different times showed that the maximum and minimum primary shoots length during the 11.69 and 10.81 , respectively 16 and $8 \mathrm{~mm}$ were obtained. Maximum primary shoots length for rice and cucumber plants under osmotic solution concentration and the interaction term respectively by Prime KNO3 and PEG solution with a duration of 12,6 and $18 \mathrm{~h}$ was obtained (Figure 2). Mohseni et al., (2010) in their study found that the maximum primary shoots length on two maize hybrid varieties of interaction with Priming for control, potassium nitrate, with concentrations of 1 and 2 percent respectively (12.64, 12.44 and $12.39 \mathrm{~mm}$ ) were obtained. Rezaei and Ramezani (2010), the highest primary shoots length on cucumber plants under interaction with Prime Time and Priming respectively by 2 percent and the lowest concentration of potassium nitrate with a concentration of $10 \%$ polyethylene glycol is (Rezaei and Ramezani, 2010). Research conducted by Rezaei and Ramezani (2010) on rice plants showed that the highest primary shoots length of interaction time and the Prime Priming respectively by 2 percent and the lowest concentration of potassium nitrate concentration with polyethylene glycol is $10 \%$.

\subsection{Germination rate and percent}

Germination for maize, rice and cucumber affected by the concentration of osmotic solution and the interaction term osmopriming concentration of 1 and 5\% probability level indicates statistical difference (Table 1, 3 and 5).Maximum germination rate of maize, rice and cucumber over time 24, 12 hours, respectively Priming solutions with PEG 5\% and KCl 2 and 4\% was observed (Table 2, 4 and 6). Rate or the rate of decrease (Kiani et al, 1998). De and Kar (1994) Determine the appropriate time to avoid the negative impact Priming be. Penalosa et al., (1993) reported that the right time Priming prevent negative effects on the germination of tomato seeds. Chojnowski et al., (1997) reported that Praymyng sunflower seeds for 3 to 5 days increased germination and seedling growth can be improved. They also cause this reaction increases in respiratory activity, the production of ATP, stimulates the activity of RNA and protein was expressed in seeds Prime. Khajeh hosseini et al., (2003) stated that sodium chloride decreases the rate of polyethylene glycol germination of soybean seed is. Basra et al., (2003) and Afzal et al., (2006) for canola plant showed that germination in response to priming increase. Priming improvement in seed germination and uniform seed germination and reduced sensitivity to environmental factors are. Faster deployment, greater stamina, faster development, earlier flowering and higher yield of seed is Priming consequences (Hafeez et al., 2007). Rezaei and Ramezani (2010) in studies on rice plant at different times Priming showed that the highest germination rate during 12 hours (the number of seeds germinated at 12.87) and the minimum time of 4 hours $(9.80$ the number of seeds germinated per day) was observed. The maximum germination rate with potassium chloride concentrations of 2 and 4 percent were from the same (number of seeds germinated at 12.41 and 12.72 days). Hosseini and Koocheki (2007) stated that the sugar beet sodium chloride and polyethylene glycol, a significant decrease in germination rate of the sugar beet cultivars.Increasing concentrations of polyethylene glycol, potassium nitrate and sodium chloride can lead to reduced germination rate, which suggests that increased salinity increases the osmotic pressure and reduce water absorption by the seed corn. Rezaei and Ramezani (2010) stated that most studies on cucumber plants in a germination rate of 12 hours (9.50) and the minimum time of 18 hours (6) was obtained. highest and the lowest germination rates were obtained with PEG 5\% and KNO3 1\%, respectively, 7.40 and 0.20 respectively. Moradi et al., (2008) reported that compared the effects of treatments osmopriming (PEG 6000) and Hidropriming (water) on germination and seedling growth of corn, the final germination speed, length, rootlet and seedling dry weight in seeds under water priming were observed. priming seed germination rate and uniformity of germination and improves the sensitivity of seeds to environmental causes. Faster deployment, greater vigor, faster development, earlier flowering and seed yield is higher than the outcomes Priming (Jianjun et al., 2007). The reports also on the maize also states that the rate of germination under the influence of pretreatment with pure water (9.28 the number of seeds per day) and potassium nitrate and polyethylene glycol with a concentration of $10 \%$ (9.25 and 8.47 the number of seeds per day) was highest (Rezaei and Ramezani, 2010). They also found that the maximum speed of over 704 hybrid maize seed germination (11.50 the number of seeds per day) treatment with a solution of polyethylene glycol osmopriming 16 and 24 hours and the minimum period of five percent ( 8.20 seed in s) osmopriming treated with a solution of potassium nitrate was two per cent to 8 hours 
(Rezaei and Ramezani, 2009). The highest germination rate, respectively, for corn, rice and cucumber under effects of treatment duration and concentration of PEG and $\mathrm{KCl}$ osmopriming for concentrations of 5 and 4 percent during the period of 24, 8 and 12 and the lowest for treatments $\mathrm{KNO} 3, \mathrm{PEG}$ and $\mathrm{KCl}$ concentrations of 2, 5 and 2 percent during the period of 8 and $12 \mathrm{~h}$ respectively (Figure 3 ).

Increasing The maximum germination rate (9.562) the interaction of cultivar $\times$ Priming for potassium nitrate (KNO3) concentration was $2 \%$ and minimum germination rate $(0.491$ and 0.245$)$ for potassium chloride $(\mathrm{KCl})$ concentration 4\% was obtained (Mohseni et al., 2010). Research conducted by Rezaei and Ramezani (2010) on rice plants showed that the germination rate for the treatment of interaction with potassium chloride at a concentration equal to $4 \%$ during $8 \mathrm{~h}(8.15)$ and lowest for treatment polyethylene glycol in concentrations of 5\% during the 8 and $12 \mathrm{~h}$ (9.33 and 9.31) was obtained. Rezaei and Ramezani (2010) on cucumber plants also express the highest germination rate under the two-factor interactions for equal treatment with $\mathrm{KCl} 4 \% \mathrm{~T} 12$ (9.85) and the lowest for equal treatment, $\mathrm{KCl} 2 \% \mathrm{~T} 12$ (5.55) was obtained. As in (1, 3 and 5) can be seen, the percentage of germination to plant rice and cucumber, respectively, were statistically affected by the concentration of solutions osmopriming and interaction of two factors, respectively, at level 1 and 5 percent showed a significant difference. The highest percentage of germination for rice and cucumber plants, respectively, during the period of 8,6 and 12 $\mathrm{h}$ were obtained (Table 2, 4 and 6). Maximum germination Priming treated water (86.67) and potassium nitrate and potassium chloride for a minimum percentage of germination with concentrations of 2 and $4 \%$ respectively ( 2.289 and 1.869) was obtained (Mohseni et al., 2010). Potassium concentrations of 2 and 4\% respectively (2.289 and 1.869) was obtained (Mohseni et al., 2010). Giri and Schillinger (2003) stated that germination of seeds of wheat for the first Prime was higher compared with control, but with a different time period was reduced to 12 Praymyng. Also reported that wheat seeds during Praymyng that it was more than 12. No advantage in germination compared to controls was observed in some cases, were lower. Rezaei and Ramezani (2010) found that the highest and lowest test on rice seed germination treatments, respectively, with time for 6 hours (100\%) and lowest with 18 hours (92\%) was obtained. Demir and Mavi (2004) reported that treatment with potassium nitrate watermelon seeds to increase germination. Prime has the seeds germinated faster than seeds with higher germination percentage was not Prime. Faster deployment, greater stamina, faster development, earlier flowering and higher yield of seed is Priming consequences (Hafeez et al., 2007). Rezaei et al., (2010) stated that most of the 640 Priming maize seed germination under treatment before the treatment with pure water (88\%) and controls, with concentrations of 10 and 5\% polyethylene glycol and potassium nitrate concentration was the result of a percent (Rezaei and Ramezani, 2010). The maximum percentage of germination in rice and cucumber plants under the two-factor interactions, respectively by Prime PEG, $\mathrm{KNO} 3$ and $\mathrm{KCl}$ concentrations of 5 and 2 percent respectively during the period of 8 and $12 \mathrm{~h}$ was obtained (Figure 4 ).

Some researchers also stated that the minimum percentage of germination of the two factors respectively by prime polyethylene glycol and potassium chloride concentrations of 5 and 2 percent during the period of 8 and 12 hours was achieved in rice (Rezaei and Ramezani, 2010). In other reports on the cucumber plant has the lowest percentage of germination under the concentration $\times$ time interactions osmopriming solutions respectively by Prime $\mathrm{KNO} 3$ 2\% T12 and $\mathrm{KCl}$ 2\% T12, respectively (Rezaei and Ramezani, 2010).

\subsection{Primary roots and shoots fresh weight}

Results analysis of variance showed that both maize and cucumber Primary roots fresh weight were statistically affected by the concentration osmopriming solutions and the interaction term solutions osmopriming concentrations were at levels 1 and 5\% (Table 1, 3 and 5). Comparison of the interaction showed that the highest root weight to plant maize and cucumber, respectively, treated osmopriming KNO3 and PEG, respectively, at time 16, 24, 12 and 18 hours with concentrations of 2 and 5\% respectively (Table 2, 4 and 6). Minimum Primary roots fresh weight and concentration of the interaction term for maize osmopriming and cucumber by the Prime soluble $\mathrm{PEG}, \mathrm{KNO} 3$ and $\mathrm{KCl}$ concentrations of 5 and 2 percent during the period of 8 and $12 \mathrm{~h}$ was obtained (Figure 5).

Maximum weight of rootlet under the priming $\times$ time interactions with the Prime osmopriming to by the Prime KNO3 2\% T18 and at least it was obtained by PEG10\% T12 and KNO3 1\% T12 (Rezaei and Ramezani, 2010). Mohseni et al., (2010) compared two hybrid maize showed that the maximum and minimum root weight under priming $\times$ cultivar interaction with potassium nitrate $(\mathrm{KNO} 3)$ and potassium chloride $(\mathrm{KCl})$ concentration of $2 \%$ was obtained. Rezaei and Ramadan (2010) on cucumber plants has been reported that the highest and lowest weight shoot times 6 and 12 hours respectively were obtained, respectively, the 0.212 and 0.138 respectively. Results showed that the duration and concentration of two-factor interactions Priming and the impact of significant statistical difference in levels 1 and 5 percent on shoot fresh weight of maize and cucumber (Table 1, 3 and 5). Maximum Primary shoots fresh weight of corn and cucumbers for the time periods of 16 and 12 hours respectively (Table 2, 4 and 6). The highest Primary shoots fresh weight for maize and cucumber plants, respectively, under the 
effects of duration and concentration of the Prime osmopriming by $\mathrm{KCl}$ Solution and $\mathrm{KNO} 3$ concentrations of $2 \%$ was achieved during a period of 16 and $18 \mathrm{~h}$ (Figure 6).

Based on fetal growth and development of seedling seed Priming affecting the rate of change varied according to species and conditions Priming. Differences in root and shoot growth was observed in the Prime onion seeds (Basra et al., 2003). Karaki (1998) root length and weight shoot (wheat and barley) on Priming reported. Harris (2005) stated that germination can quickly produce a deep root system to dry before the upper layers and slow germination, seedling growth, the lack of uniformity in the field. Ghana and Schillinger (2003) stated that it can produce rapid germination and deep root system before it is dry, the upper layers and slow germination, seedling growth, the lack of uniformity in the field. Kalhor (2009) stated in black cumin rootlet maximum weight of KNO3 treatment with $5 \%$ concentration at 36 hours $(94.33 \mathrm{mg})$ and PEG treated with a concentration of at least about $10 \%$ at $12 \mathrm{~h}(46.67 \mathrm{mg})$ was. Also related to the treatment of wet weight shoot Priming KNO3, KNO3 concentration of $1 \%$ at $12 \mathrm{~h}$ and $24 \mathrm{~h}$ at a concentration of 5\% (respectively 176 and $175.5 \mathrm{mg}$ ) was observed. Minimum weight for more treatments shoot $\mathrm{KCl}$ concentration of $1 \%$ and controls (respectively 131.7 and $129.7 \mathrm{mg}$ ) is. Sivritepe et al., (2005) reported that the effect of different pre-treatments on melon seedlings gain higher levels of stress more than is observed. The lowest shoot fresh weight, respectively, for potassium nitrate (KNO3) and potassium chloride $(\mathrm{KCl})$ concentrations were 2 and 4 percent against the consecutive 0.22 and $0.352 \mathrm{~g}$, respectively (Mohseni et al., 2010).

\subsection{Primary root/ primary shoot length proportion $(R / S)$}

Test results (Table 1, 3 and 5) shows that the concentration of osmotic solution concentration and the interaction term osmopriming significant differences in levels 1 and 5 percent on the Primary root/ primary shoot length proportion $(\mathrm{R} / \mathrm{S})$ of maize, of rice and cucumber. Comparison of the interaction showed that the highest Primary root/ primary shoot length proportion(R/S) for maize, rice and cucumber, respectively, treated osmopriming PEG, $\mathrm{KNO} 3$ and $\mathrm{KCl}$, respectively, during the period of 24,8 and 6 hours with a concentration of 51,2 , and $4 \%$ were obtained (Table 2, 4 and 6). Kalhor (2009) stated squash seeds in paper length and weighing more than R / S, respectively, for the use of potassium nitrate concentration Prime $5 / 0 \%$ at 36 hours (2.37) and Prime with a concentration of $4 \%$ KCL 12 hours (0.42) and also less than the length of treatment with $2 \%$ KCL Prime in 12 hours (1.41), respectively. The maximum length of root to shoot ratio $(\mathrm{R} / \mathrm{S})$, respectively, for treatments with a time of 8 hours $(0.532)$ with at least 4 hours $(0.432)$ were obtained, and the maximum and minimum length ratio $(\mathrm{R} / \mathrm{S})$ to polyethylene glycol and potassium nitrate concentrations were 5, 10 and $2 \%$ respectively (Rezaei and Ramezani, 2010). Rezai and Ramezani (2010) The effect on seed germination cucumber Priming concluded that the maximum and minimum length of 6 hours, respectively, for treatments with time (1.970) and the minimum time of 18 hours (1.660) was obtained. The maximum and minimum Primary root/ primary shoot length proportion(R/S) and PEG 5\% and $\mathrm{KCl} 4 \%$, respectively, concentrations of 4 and 5 percent respectively. Rezaei et al., (2010) The effect on the germination of corn Priming concentrations studied and observed that the greatest proportion of root length to shoot for the control treatment (1.613\%) and lowest root to shoot length proportion R/S for the treatment of Polyethylene Glycol and potassium nitrate with concentrations of 5, 10 and one percent respectively (1.22, 1.26 and 1.22 percent) was achieved. Investigation of osmopriming research on maize, 704 showed the highest and lowest proportion of longitudinal root to shoot, respectively (1.484) for the treatment osmopriming with Peg for 24 hours, and $\mathrm{KCl}(1.206)$ in the treatment osmopriming to 8 hours was achieved (Rezaei and Ramezani, 2009). The maximum and minimum length $(\mathrm{R} / \mathrm{S})$ of the interaction time $\times$ Priming with potassium nitrate and potassium chloride with a concentration of $4 \%$ was obtained (Figure 7). Rezaei and Ramezani (2010) in cucumber plants expressed the maximum and minimum length of root to shoot ratio under the concentration $\times$ time interactions were Prime osmopriming by PEG $10 \% \mathrm{~T} 12$ and $\mathrm{KCl} 4 \% \mathrm{~T} 18$ was obtained (Rezaei and Ramezani, 2010).

\subsection{Primary root/ primary shoot fresh weight proportion $(R / S)$}

Results Analysis of variance showed that the ratio of Primary root/ primary shoot fresh weight proportion(R/S) maize, rice and cucumber under the influence of statistical term solutions osmopriming concentration and interaction between 1 and 5 percent error factor levels were significantly different

(Table 1, 3 and 5). The maximum Primary root/ primary shoot fresh weight proportion(R/S) for maize, rice and cucumber respectively by Prime solutions osmopriming $\mathrm{KNO}$, $\mathrm{PEG}$ and $\mathrm{KCl}$ concentrations of 2, 5, 4, 1, 2 and 4 percent during the period 24, 12 and $18 \mathrm{~h}$ was observed (Table 2, 4 and 6). More weight than the lowest R/S, respectively, for potassium nitrate $(\mathrm{KNO} 3)$ and potassium chloride $(\mathrm{KCl})$ concentrations were obtained 2 and $4 \%$ (Mohseni et al, 2010). Maximum Primary root/ primary shoot fresh weight proportion (R/S) by the Prime $\mathrm{KCl}$ concentration was thus 4\% (Rezaei and Ramezani, 2010). Kalhor (2009) expressed the caraway root fresh weight up to 36 hours of treatment Kno3 concentration of $5 \%$ (33/94 mg) and the minimum concentration of $10 \%$ PEG 
treatment for 12 hours $(46.67 \mathrm{mg})$ is. The shoot fresh weight of about $1 \%$ concentration in $12 \mathrm{~h}$ treatments Priming KNO3 concentration of $5 \%$ at $24 \mathrm{~h}$ (respectively 176 and $175.5 \mathrm{mg}$ ) is. Rezai and Ramezani (2010) Effect Priming concentrations on cucumber seed germination studies and stated that the lowest shoot fresh weight concentration of $1 \%$ for $\mathrm{KCl}$ treatments and controls (respectively, 131.7 and $129.7 \mathrm{~mm} \mathrm{~g}$ ) is. The maximum weight ratio of root to shoot under 18 hours time (0.92) were obtained. The highest and lowest ratio of root to shoot fresh weight, respectively, and $\mathrm{KCl} 4 \%$ PEG $10 \%$ was achieved. The maximum Primary root/ primary shoot fresh weight proportion(R/S) before treatment with potassium chloride concentration of $4 \%(2.523 \%)$ and minimum, respectively, for the treatment of polyethylene glycol, potassium nitrate and 640 were observed in corn plants (Rezaei et al. , 2010). The maximum Primary root/ primary shoot fresh weight proportion(R/S), respectively, under the effect of duration and concentration Priming to plant maize, rice and cucumber respectively by the Prime Solution KNO3, PEG and KNO3 concentrations of 1 and $10 \%$ during at 24, 12 and $16 \mathrm{~h}$ was obtained (Figure 8).

More weight than the minimum number of interactions with potassium nitrate and potassium chloride concentrations Priming $\times 2$ and 4 percent respectively $(0.099$ and $0.081 \mathrm{~g})$ was obtained (Mohseni et al., 2010). Also Rezaei and Ramezani (2010) on rice plants expressed the maximum Primary root/ primary shoot fresh weight proportion(R/S) under Priming $\times$ time interaction with potassium nitrate in a period of 4 hours was achieved. Rezaei and Ramezani (2010) reported that in cucumber seeds maximum root fresh weight ratio how to shoot under the concentration $\times$ time interactions with $\mathrm{KNO} 31 \% \mathrm{~T} 6$ osmopriming solution was obtained. They also said maximum and minimum Primary root/ primary shoot fresh weight proportion $(\mathrm{R} / \mathrm{S})$ of the interaction term and concentration osmopriming with KNO3 and PEG solutions with concentrations of 2 and $10 \%$ was achieved in 704 maize plants (Rezaei and Ramezani, 2009).

\subsection{Primary root/ primary shoot dry weight proportion $(R / S)$}

Among the sources of variation, the concentration of osmopriming and interaction levels 1 and 5 percent on the proportion of Primary root/ primary shoot dry weight proportion(R/S) of maize, rice and cucumber were significant (Table 1, 3 and 5). Comparison of the interaction showed that the maximum Primary root/ primary shoot dry weight proportion $(\mathrm{R} / \mathrm{S})$ for rice and cucumber plants, respectively, by $\mathrm{KNO} 3$ solutions with concentrations of 1 and 2\% was observed (Table 2, 4 and 6). One of the main reasons that can shoot dry weight to justify a high potential for mobility and transport of nutrients from the cotyledons to the embryonic axis. It is notable factors that affect embryonic axis growth rate can have on the mobility and transfer of nutrients from the cotyledons to the embryonic axis affect (Bagheri et al., 2000). Seed germination is not necessarily associated with a strong stem and may be high but the germination percentage and root and the stems are not produced strong. Poor seedling growth in the later stages are also able to produce the desired number of tillers and reproductive organs are not appropriate. In dry conditions there is probably a poor plant roots and stems are weak in the early stages of life (Kafi and Goldani, 2000). The maximum weight proportion R/S for the treatment of potassium nitrate (KNO3) and potassium chloride $(\mathrm{KCl})$ concentrations of 1 and $2 \%$ (respectively 6.546 and 6.503) was obtained (Mohseni et al., 2010). Kalhor (2009) and Khdaday et al., (2003) also studied the effect of Priming onion seed germination characteristics in terms of salinity showed that seedling dry weight of sodium chloride does not affect View Post Priming. Probably due to the low mass, seed germination, seedling countless for a better environment is created, it may be more dry weight and seedling production to be less affected. Rezaei and Ramezani (2010) in a test on rice seed reported that the highest and lowest concentrations of Priming Primary root/ primary shoot dry weight proportion $(\mathrm{R} / \mathrm{S})$ respectively by the Prime potassium chloride, potassium nitrate and potassium chloride concentrations of 1, 2 and 4 percent during the 12,8 and $12 \mathrm{~h}$ was obtained. The growth of embryonic axis and seed Priming affect the rate of change varies according to species and conditions Priming. Differences in root and shoot growth between seeds and Prime No adverse environmental conditions are more apparent. Root and shoot growth in the Prime concluded onion seeds (Basra et al., 2006). Karaki (1998) and increased root length and shoot fresh weight (wheat and barley) on Praymyng reported. Jet et al., (1998) in seeds of cabbage root growth due to increased bralky priming were noted. Harris et al., (2005) stated that germination can quickly produce a deep root system to dry before the upper layers and slow germination, seedling growth, the lack of uniformity in the field. Also Rezaei and Ramezani (2010) expressed the highest ratio of root to shoot dry weight, respectively by the Prime $\mathrm{KCl} 4 \% \mathrm{~T} 6$ treatments and the lowest $\mathrm{KNO} 3$ 1\% T18, KNO3 2\% T6 and $\mathrm{KCl} 2 \% \mathrm{~T} 18$ in cucumber was observed (Rezaei and Ramezani, 2010). Rezaei et al., (2010) on hybrid maize 640 to conclude that most of the dry weight of root to shoot for the treatment of potassium chloride concentration of $4 \%$ against ( 8.43 percent) and lowest Primary root/ primary shoot dry weight proportion (R/S) for the treatment of potassium nitrate concentration of one percent (2.88 percent) were obtained. The Rezaei and Ramezani (2009) The effect on the germination of corn 704 osmopriming concluded that the highest and lowest ratio of root to shoot dry weight, respectively 11.6 and 7.83 grams for 24 and 16 hours was achieved in times. Also Rezaei and Ramezani (2010) expressed the Primary 
root/ primary shoot dry weight proportion $(\mathrm{R} / \mathrm{S})$, respectively by the Prime $\mathrm{KCl} 4 \% \mathrm{~T} 6$ treatments and the lowest KNO3 1\% T18, KNO3 2\% T6 and KCl 2\% T18 in Cucumber seeds were observed (Rezaei et al., 2010). Rezaei et al., (2010) in a series of laboratory studies on two maize hybrids reported maximum dry weight ratio R/S under the interaction of cultivar $\times$ Priming for potassium nitrate at a concentration of $1 \%(9.009)$ and the lowest Primary root/ primary shoot dry weight proportion $(\mathrm{R} / \mathrm{S})$ for treatment with potassium chloride concentration of $4 \%$ to 0.427 were obtained (Mohseni et al., 2010) (Figure 9).

\subsection{Normal and abnormal seedlings number}

This trait on maize, rice and cucumber under the influence of statistical term, solution concentration and interactions Osmopriming concentration levels 1 and 5\% were significantly different (Table 1, 3 and 5). And also most common in maize seedlings by the Prime Kcl osmotic solution concentration of $4 \%$ was observed (Table 2, 4 and 6). While the minimum number of ordinary cucumber seedlings under the effect of duration and concentration, respectively osmopriming.

Prime with a $2 \%$ solution of $\mathrm{KNO} 3$ and $\mathrm{KCl}$ concentrations over time periods were 12 and $18 \mathrm{~h}$ (Figure 10). Research conducted by Rezaei and Ramezani (2010) suggests that most of the rice seed The lowest number of seedlings under normal and Priming interaction with potassium nitrate and polyethylene glycol with a concentration of 5\% was obtained (Rezaei and Ramezani, 2010). Kalhor (2009) stated that the maximum number of buds in the ordinary squash seeds in paper consumption in the PEG concentration of 5\% at $12 \mathrm{~h}$ (43.66 germ) and the minimum concentration of $1 \%$ in 36 hours $\mathrm{Kno} 3$ conditions of the times ( 25 abnormal growth) respectively. Rezaei and Ramezani (2010). The study on cucumber seeds at different times priming stated that the highest and lowest, respectively, with times of 6 hours (25) and $18 \mathrm{~h} \mathrm{(23)} \mathrm{was} \mathrm{obtained.} \mathrm{Rezaei} \mathrm{and} \mathrm{Ramezani} \mathrm{(2009)} \mathrm{is} \mathrm{also} \mathrm{in}$ the evaluation time of 704 maize seed priming concluded that most the lowest number of seedlings and ordinary 24.50 and 22 respectively for the treatments for 24 hours and 16 hours was achieved with the minimum, maximum and minimum number of normal seedlings, respectively KNO3 solutions with on centrations of 4 and of a percent. Rezaei and Ramezani (2010) stated that this minimum number of normal seedlings under a two factor interactions were with Prime $\mathrm{KNO} 32 \% \mathrm{~T} 12$ and $\mathrm{KCl} 2 \% \mathrm{~T} 18$ on cucumber seeds were obtained.

\subsection{Vigor 1 and 2 index}

These traits (Vigor 1 and 2 index) under the influence of artificial drying and increase the humidity decreases, but the difference between the treatment Osmopriming of moisture uptake for both the index reached a minimum.Most of the rice plant Vigor a period of 8 hours, respectively (Table 4). (Artola et al., 2003) also pointed to the positive effect Hydropriming on Vigorith Lotus Seed. For the standard germination, germination rate, seedling length, and criteria 1 and 2, the best treatment Vigor Osmopriming potential-8 and -12 hour period, the results and provides an acceptable time and cost of economic and human resources to The results are similar to other treatment components, cost effective and is recommended for soybean. Likely more concentration and duration of poisoning or toxic substances in the seeds are produced. Some researchers have reported this issue in various products (Buyukalaca, 1999). The highest and lowest indicator of an interaction term Vigor Osmopriming solution concentration respectively by Prime KNO3 and PEG concentrations of 2 and $10 \%$ respectively at 12 and $4 \mathrm{~h}$ were obtained (Figure 11). In this regard, Rezaei et al., (2010) reported that one of the highest and lowest index Vigor interactions Time $\times$ Priming order for potassium nitrate and polyethylene glycol with a concentration of 2 and $10 \%$ respectively at 12 and $4 \mathrm{~h}$ was obtained, which is consecutive to 986.8 and 546.3, respectively.

As is evident in the analysis of variance, statistically significant impact on the duration and concentration of 2 Vigor Osmopriming solutions, respectively, in a 5\% probability level showed a significant difference (Table 3). Maximum and minimum index by $\mathrm{KCl}$ Prime Vigor 2 concentration was obtained (Table 4). The best way to pre-treatment of water 2 Vigor, 5 and $10 \%$ polyethylene glycol concentration, nitrate concentration was $1 \%$ (respectively, 18.99, 16.89, 18.56, 15.97 and 17.48) was produced in maize seeds Rezaei et al., (2010). The Mohseni et al., (2010) expressed the highest and lowest index 2 for Prime Vigor water, potassium nitrate and potassium chloride concentrations of 2 and $4 \%$ vs. $19.43,0.627$ and 0.512 was obtained.

\section{Conclusion}

The results of this study can be concluded that the different treatments before germination of maize, rice and cucumber under drought stress conditions improved, and the increased power and speed of the seed that ultimately increase the percentage of seed germination these conditions will be effective as possible in the final performance. On the other hand, under controlled laboratory study is required by way possible mechanism is similar to the normal stress. The municipality of planting seeds in the soil reduces the secondary is heated. The different treatments of the seeds before germination are more at a time can produce more biomass. The advantage of such 
salts and nutrients necessary to supply nitrogen for protein synthesis during germination is. But prior to this test in a complementary field to confirm the usefulness of this method is.

\section{Reference}

Afzal, I., Basra, S. M. A., Ahmad, R., \& Iqbal, A. (2002). Effect of different seed vigour enhancement techniques on hybrid maize (zea mays L.). Pak. J. Agri. Sci., 39, 109-112.

Afzal. A., Aslam, N., Mahmood, F., Hameed, A., Irfan, S., \& Ahmad, G. (2006). Enhan cement of germination and emergence of canola seeds by different priming Techniques. Garden depesquisa Bio., 16(1), 19- 34.

Ali Abadi, A., \& M, Lotfi. (2008). Priming impact and potential of various substances on the osmotic seed melon, cucumber and watermelon. Seed Science and Technology Proceedings of the National Congress of Iran. Gorgan, Pp. 53-46.

Anonymous. (2010). Internal Marnamh Agriculture Organization of Mazandaran province. P 140.

Artola, A., Carrillo-Castaneda, G., \& Santos, G. D. L. (2003). Hydropriming: A Strategy to increase Lotus Corniculatus L. Seed vigor. Seed Science and Technology, 31, 455-463.

Ashraf, M., \& Foolad, M. R. (2005). Pre-sowing seed treatment- a shotgun approach to improve germination growth and crop yield under saline and none- saline conditions. Advan. Agron, 88, 223-271. http://dx.doi.org/10.1016/S0065-2113(05)88006-X

Bagheri Kazemabad, A., \& Sarmadnia, G. H. (2007). Studying ability to use polyethylene glycol 6000 to study drynees in (Onobrychis Viciolis scoop) in plantlet stage. Agriculture resources and Science Magazine, 5(1), 1-9.

Basra, A, Farooq, S. M, Afzal, I., \& Hussain, M. (2006). Influence of osmopriming on the germination and early seedling growth of coarse and fine rice. Int. J. Agr. Biol., 8, 19-21.

Basra, S. M. A., Pannu, I. A., \& Afzal, I. (2003). Evaluation of seedling vigour of hydro and matriprimed wheat ( Triticum aestivum L.) seeds. Int. Agri. Biol., 5, 121- 123.

Bewley, J. D., \& Black, M. (1998). Seed:physiology of development and germination second edition. New York, Plenum press.

Buyukalaca, S. (1999). The effect of Nacl priming on salt tolerance in melon seedling. Acta Horticulture, 492, 77-84.

Chojnowski, F. C., \& Come, D. (1997). Physiological and biochemical changes induced in sunflower seeds by osmopriming and subsequent drying, storage and aging. Seed science Research, 7, 323-331. http://dx.doi.org/10.1017/S096025850000372X

De, F., \& Kar, R. K. (1994). Seed germination and seedling growth of mung bean (Vigna radiate) under water stress in duced by PEG-6000. Seed Science and Technology, 23, 301-304.

Demir, H., \& Mavi. K. (2004). Seed priming of male steile muskmelon (Cucumis melo L.) for low temperature germination. Seed Scince and Technology, 23, 881-884.

Dorosti, H. (2000). The final report compares the performance of hybrid rice varieties and international line. National Rice Research Institute.

F. A. O. Production year book. (2009). Food and Aricultural organization of united Nation, Rome, Italy, 51, 209p.

Farooq, M. S., Basra, M. A., Tabassum, R., \& Afzal, I. (2006). Enhancing the performance of direct seeded fine rice by seed priming. Plant. Prob. Sci., 4, 446- 456. http://dx.doi.org/10.1626/pps.9.446

Ghana, S. G., \& Schillinger, W. F. (2003). Seed priming winter wheat for germination, emergence, and yield. Crop science, 43, 2135-2141.

Ghavami, F., Melboy, M. A., Ghanadha, M., Yazdi Samadi, B., Mozafari, G., \& Aghaee M. G. (2004). Surveying reaction of possible varieties of Iranian wheat to salt tension inseeding and plantlet stage. Iran Agriculture Sciences Magazine, 35(2), 453-461.

Giri, G. S., \& Schillinger, W. F. (2003). Seed priming winter wheat for germination, emergence and yield. Crop Sci, 43, 2135-2141. http://dx.doi.org/10.2135/cropsci2003.2135

Hafeez, U. R., Farooq, M., \& Afzal, I. (2007). Latc Sowing of wheat by seed priming- DAWN- Business.

Harris, D. (2005). Priming seed. DFID plant sciences research programme, centre for Arid Studies. University of Bangor, 18, 22-25. 
Hosseini, A., \& Koocheki, A. (2007). Priming effect of different treatments on the germination percentage and speed of four varieties of sugar beet seed. Journal Iranian Agricultural Research, 4(1), 22-15.

JianJun, F., Kunjie, C., Giyoen, K., Yong, X., Xiang Yang, Z., \& Jian Qiang, L. (2007). Effect of seed priming on seedling growth and disinfection to acidovorax avenae sub SP. Citrulli in triploid watermelon seeds. Acta Phytopathologica Sinica, 37(5), 528-534.

Kafi, M., \& Goldani, M. (2000). The effect of water potential and produce substance on sptouting of 3 cultivated plants wheat, peas. Agricultural Source and Science Magazine, 1(15), 121-132.

Kalhor, V. (2009). Study of osmopriming effects on germination and features of several herbal seedling and oily plants cultivation. M.Sc agricultural. Islamic Azad University, Tehran Research and Science Unites.

Karaki, G. N. (1998). Response of wheat and barley during germination to seed osmopriming at different water potential. Journal of Agronomy and Crop Science, 181, 4, 229-235. http://dx.doi.org/10.1111/j.1439-037X.1998.tb00422.x

Kaurs, A., Gupta, K., \& Kaur, N. (2002). Effect of osmo and hydro priming of chickpea seed sun seedling growth and carbohydrate metabolism under water deficit stress. Plant Growth Regulation, 37, 12-22.

Khajeh hosseini, A., Powell, A., \& Bingham, I. J. (2003). The interaction between salinity stress and vigour during germination of soyabean seeds. Seed Sci and Technol, 31, 715-725.

Khodabandeh, N. (1992). Grain farming. Tehran University Press, 401.

Khodadadi, M., Omid-Beigi, M., \& Khosh Kholgh, S. (2003). The effect of seed Priming on the germination characteristics of Kashan white onion cultivars under salt stress. Soil and Water Science, vol 17, No. 1.

Kiani, M., Bagheri, R., \& Nezami, A. (1997). Reactions genotypes to drought tension resulting from polyethylene glycol 6000 in seeding stage. Agriculture industries and Sciences Magazine, 2(1), 45-55.

Kim, S. H., \& Kang, C. (1987). Vigor determination in barley seed by the multiple criteria. Korean Journal of Crop Science, 32, 417- 427.

Maguire, J. D. (1962). Speed of germination - aid in selection and evaluation for seedling emergence and vigour. Crop Sci, 2, 176-177. http://dx.doi.org/10.2135/cropsci1962.0011183X000200020033x

Mohseni, A. Rezaei, R., Ramezani, M., \& Mobasser, H. R. (2010). Osmopriming impact on the properties of the hybrid seed corn, 704 and 640. Journal of Crop Physiology, 2, 25-44.

Moradi Dezfuli, P., Sharif-Zadeh, F., \& Janmohammadi, M. (2008). Influence of priming techniques on seed Germination behavior of Maize inbred lines (zea mays L.). ARPN Journal of Agricultral and Biological Science, $3(3)$.

Nascimento, W. M. (2003). Muskmelon seed germination and seedling development in response to seed priming. Scientia Agricola, 6(1), 71-75. http://dx.doi.org/10.1590/S0103-90162003000100011

Nichols, M. A., \& Heydecker, W. (1968). Two approaches to the study of germination date. Proc. Int. seed test. Ase., 33, 531-540.

Parera, C. A., \& Cantiffe, D. J. (1994). Pre-Sowing seed priming. Tlortic. Rev., 16, 109-141.

Penalosa, A. P. S., \& Eira, M. T. S. (1993). Hydration - dehydration treatments on tomato seeds (Lgcopersicon esculentum mill.). Seed Science and Technology, 21, 309-316.

Pizzeghello, D., Nicolini, G., \& Nardi, S. (2001). Hormone-like activity of humic substances infagus sylvaticae forests. New. Phytologist, 51, 647- 657. http://dx.doi.org/10.1046/j.0028-646x.2001.00223.x

Rezaei, R. \& Ramezani, M. (2010). Osmopriming study on the characteristics of rice seed (Oryza sativa L.) cultivars Neda. Journal of Agricultural Science and Sustained Production.

Rezaei, R., \& Ramezani, M. (2010). Osmopriming effects of different treatments on seed germination characteristics of cucumber (Cucumis sativus L.). Journal of Plants and Ecosystems.

Rezaei, R., \& Ramezani, M. (2009). Osmopriming effect on seed germination characteristics of forage maize single cross 704. Seed Science and Technology of Iran, Volume 1, Issue3. P.

Rezaei, R., Mohseni, A., Ramezani, M., \& Mobasser, H. R. (2010). The Priming effect on germination characteristics of maize seed $\neg$ 640. Journal of Modern Agriculture, 4(1), 49-61.

Sanchez, J. A., Munoz, B. C., \& Fresneda, J. (2001). Combine effects of hyrdening hydration-dehydration and heat shock treatments on the germination of tomato, pepper and cucumber. Seed Science and Technology, 29, 691-697. 
Sivritepe, H. O., Sivritepe, N., Eris, A., \& Turhan, E. (2005). The effects of $\mathrm{NaCl}$ pre treatmants on salt tolerance of melons grown under long-term salinity. Scientia Horticulurae, 106, 568-581. http://dx.doi.org/10.1016/j.scienta.2005.05.011

Subedi, K. D., \& Ma, B. I. (2005). Seed priming does not improve corn yield inahumid temperate environment. Agron j, 97, 211- 218.

Zeinali, A., Soltani, A., \& Golshani, S. (2001). Reaction of seeding parts to tension in rape (Brassica napus L.). Iran Agriculture Sciences Magazine, 33(1), 137-145.

Table 1. Analyzse of variance of (Mean Square) studid characteristics under in Osmo-priming solutions concentration and duration and treatments of hybrid Maize (Zea mays L. CV. Single cross 704) seeds

\begin{tabular}{|c|c|c|c|c|c|c|c|c|c|c|c|}
\hline S.O.V & df & $\begin{array}{c}\text { Primary } \\
\text { root } \\
\text { length }\end{array}$ & $\begin{array}{c}\text { Primary } \\
\text { root } \\
\text { length }\end{array}$ & $\begin{array}{c}\text { Germination } \\
\text { rate }\end{array}$ & $\begin{array}{c}\text { Primary } \\
\text { root } \\
\text { fresh } \\
\text { weight }\end{array}$ & $\begin{array}{c}\text { Primary } \\
\text { shoot fresh } \\
\text { weight }\end{array}$ & $\begin{array}{c}\text { Primary } \\
\text { weight } \\
\text { root dry }\end{array}$ & $\begin{array}{c}\text { Primary root/ } \\
\text { primary shoot } \\
\text { length } \\
\text { proportion } \\
(\mathrm{R} / \mathrm{S})\end{array}$ & $\begin{array}{c}\text { Primary root/ } \\
\text { primary shoot } \\
\text { fresh weight } \\
\text { proportion } \\
(\mathrm{R} / \mathrm{S})\end{array}$ & $\begin{array}{c}\text { Primary root/ } \\
\text { primary } \\
\text { shoot dry } \\
\text { weight } \\
\text { proportion } \\
(\mathrm{R} / \mathrm{S})\end{array}$ & $\begin{array}{c}\text { Normal } \\
\text { seedling } \\
\text { s number }\end{array}$ \\
\hline Replication & 2 & $\begin{array}{l}25.784 * \\
*\end{array}$ & * 1.987 & $0.359 \mathrm{~ns}$ & $0.030 \mathrm{~ns}$ & $0.000 \mathrm{~ns}$ & $0.001 \mathrm{~ns}$ & $* * 0.112$ & $0.002 \mathrm{~ns}$ & $0.541 \mathrm{~ns}$ & $3.722 \mathrm{~ns}$ \\
\hline $\begin{array}{l}\text { Duraation } \\
\text { (A) }\end{array}$ & 2 & $\begin{array}{l}71.461 * \\
*\end{array}$ & $3.582 * *$ & $* * 23.369$ & $1.422 * *$ & $* * 0.026$ & $* 0.050$ & $* * 0.363$ & $* * 0.050$ & $* * 51.360$ & $\begin{array}{l}* * \\
28.168\end{array}$ \\
\hline $\begin{array}{l}\text { Osmo- } \\
\text { priming (B) }\end{array}$ & 5 & $\begin{array}{l}12.047 * \\
*\end{array}$ & $0.514^{* *}$ & $* * 0.894$ & $* * 0.086$ & $0.001 \mathrm{~ns}$ & $0.004 \mathrm{~ns}$ & $0.059^{* *}$ & $* * 0.006$ & $10.663 \mathrm{~ns}$ & $2.489 * *$ \\
\hline$(\mathrm{A} \times \mathrm{B})$ & 10 & $7.254 * *$ & $0.560 \mathrm{~ns}$ & ** 1.208 & $* * 0.092$ & $0.007 \mathrm{~ns}$ & $0.014 \mathrm{~ns}$ & $0.49 \mathrm{~ns}$ & * 0.004 & $18.524 \mathrm{~ns}$ & $3.389 \mathrm{~ns}$ \\
\hline $\mathrm{Eb}$ & 34 & 0.928 & 0.555 & 0.245 & 0.019 & 0.004 & 0.010 & 0.020 & 0.002 & 9.407 & 1.742 \\
\hline C.V (\%) & & 6.25 & 6.63 & 4.71 & 10.94 & 15.48 & 29.42 & 10.40 & 13.02 & 22.49 & 5.68 \\
\hline
\end{tabular}

ns, not signiticant and **and* significantly on probability level of 1 and 5\%, respectively.

Table 2. Mean comparisons of studied characteristics of hybrid Maize (Zea mays L. CV. Single cross 704) seeds under duraation and concatratin of osmo-priming solutions.

\begin{tabular}{|c|c|c|c|c|c|c|}
\hline Treatment & $\begin{array}{l}\text { Primary shoot } \\
\text { length } \\
(\mathrm{mm})\end{array}$ & $\begin{array}{l}\text { Primary shoot } \\
\text { tresh weight (gr) }\end{array}$ & $\begin{array}{c}\text { Primary root dry } \\
\text { weight (gr) }\end{array}$ & $\begin{array}{c}\text { Primary root/ } \\
\text { primary shoot } \\
\text { length proportion } \\
(\mathrm{R} / \mathrm{S})\end{array}$ & $\begin{array}{c}\text { Primary root/ } \\
\text { primary shoot } \\
\text { dry weight } \\
\text { proportion } \\
(\mathrm{R} / \mathrm{S})\end{array}$ & $\begin{array}{c}\text { Normal } \\
\text { seedlings } \\
\text { number }\end{array}$ \\
\hline $\mathrm{T} 8$ & $10.81 b$ & $0.3633 b$ & $0.2839 \mathrm{a}$ & $1.206 \mathrm{~b}$ & $8.582 b$ & $23.17 b$ \\
\hline $\mathrm{T} 16$ & $11.69 \mathrm{a}$ & $0.4361 \mathrm{a}$ & $0.3306 \mathrm{a}$ & $1.391 \mathrm{a}$ & $7.833 b$ & $22.00 \mathrm{c}$ \\
\hline $\mathrm{T} 24$ & $11.18 \mathrm{~b}$ & $0.3817 b$ & $0.3894 \mathrm{a}$ & $1.484 \mathrm{a}$ & $11.06 \mathrm{a}$ & $24.50 \mathrm{a}$ \\
\hline PEG $5 \%$ & $10.81 b$ & $0.3933 a$ & $0.3611 \mathrm{a}$ & $1.480 \mathrm{a}$ & $10.88 \mathrm{a}$ & $23.00 \mathrm{ab}$ \\
\hline PEG $10 \%$ & $11.69 \mathrm{a}$ & $0.3978 \mathrm{a}$ & $0.3356 \mathrm{a}$ & $1.300 \mathrm{~b}$ & $8.487 \mathrm{a}$ & $23.44 \mathrm{ab}$ \\
\hline KNO3 $1 \%$ & $11.18 \mathrm{ab}$ & $0.3789 \mathrm{a}$ & $0.3300 \mathrm{a}$ & $1.298 b$ & $9.176 \mathrm{a}$ & $22.56 b$ \\
\hline KNO3 $2 \%$ & $0.175 \mathrm{c}$ & $0.3844 \mathrm{a}$ & $0.3111 \mathrm{a}$ & $1.440 \mathrm{ab}$ & $8.667 \mathrm{a}$ & $23.00 \mathrm{ab}$ \\
\hline $\mathrm{KCl} 2 \%$ & $11.37 \mathrm{ab}$ & $0.4033 \mathrm{a}$ & $0.3578 \mathrm{a}$ & $1.294 b$ & $9.901 \mathrm{a}$ & $23.22 \mathrm{ab}$ \\
\hline $\mathrm{KCl} 4 \%$ & $10.78 b$ & $0.4044 \mathrm{a}$ & $0.3122 \mathrm{a}$ & $1.350 \mathrm{ab}$ & $7.844 a$ & $24.11 \mathrm{a}$ \\
\hline
\end{tabular}

*: In each column and each group cares with same letter had no significant diffrences in probability level of 5\% based on Duncan multiplerange test. 
Table 3. Analyzse of variance of (Mean Square) studid characteristics under in Osmo-priming solutions concentration and duration and treatments of Rice (Oryza Sativa L. Nade Variety) seeds

\begin{tabular}{|c|c|c|c|c|c|c|c|c|c|c|c|c|c|}
\hline S.O.V & df & $\begin{array}{c}\text { Primary } \\
\text { root } \\
\text { length }\end{array}$ & $\begin{array}{c}\text { Primary } \\
\text { shoot } \\
\text { length }\end{array}$ & $\begin{array}{l}\text { Primary } \\
\text { seedling } \\
\text { length }\end{array}$ & $\begin{array}{c}\text { Primary } \\
\text { root/ } \\
\text { primary } \\
\text { shoot } \\
\text { length } \\
\text { proportion } \\
(\mathrm{R} / \mathrm{S})\end{array}$ & $\begin{array}{c}\text { Primary } \\
\text { root/ } \\
\text { primary } \\
\text { shoot } \\
\text { fresh } \\
\text { weight } \\
\text { proportion } \\
(\mathrm{R} / \mathrm{S})\end{array}$ & $\begin{array}{c}\text { Primary } \\
\text { root/ } \\
\text { primary } \\
\text { shoot dry } \\
\text { weight } \\
\text { proportion } \\
(\mathrm{R} / \mathrm{S})\end{array}$ & $\begin{array}{c}\text { Normal } \\
\text { seedlings } \\
\text { number }\end{array}$ & $\begin{array}{c}\text { Abnormal } \\
\text { seedlings } \\
\text { number }\end{array}$ & $\begin{array}{c}\text { Germination } \\
\text { rate }\end{array}$ & $\begin{array}{c}\text { Germination } \\
\text { percent }\end{array}$ & $\begin{array}{l}\text { Vigor } 1 \\
\text { index }\end{array}$ & $\begin{array}{c}\text { Vigor } 2 \\
\text { index }\end{array}$ \\
\hline Replication & 2 & $0.024 \mathrm{~ns}$ & $\begin{array}{l}0.412 \\
\text { ns }\end{array}$ & $0.076 \mathrm{~ns}$ & $0.001 \mathrm{~ns}$ & $0.002 \mathrm{~ns}$ & $0.002 \mathrm{~ns}$ & $2.463 \mathrm{~ns}$ & $0.296 \mathrm{~ns}$ & $0.146 \mathrm{~ns}$ & $1.852 \mathrm{~ns}$ & $\begin{array}{l}23437.227 \\
\text { ns }\end{array}$ & $1.389 \mathrm{~ns}$ \\
\hline $\begin{array}{l}\text { Duraation } \\
\text { (A) }\end{array}$ & 2 & $5.324 * *$ & $\begin{array}{l}8.027 \\
* *\end{array}$ & $17.135 * *$ & $0.046 * *$ & $0.005 \mathrm{~ns}$ & $0.007 \mathrm{~ns}$ & $18.019 * *$ & $1.407 *$ & $45.970 * *$ & $7.060 \mathrm{~ns}$ & $\begin{array}{l}100712.03 \\
* *\end{array}$ & $6.195 * *$ \\
\hline $\begin{array}{l}\text { Osmo- } \\
\text { priming (B) }\end{array}$ & 5 & $0.221 * *$ & $\begin{array}{l}0.583 \\
* *\end{array}$ & $0.0270 \mathrm{~ns}$ & $0.022 * *$ & $0.024 *$ & $0.017 \mathrm{~ns}$ & $1.396 \mathrm{~ns}$ & $0.341 \mathrm{~ns}$ & $4.247 * *$ & $0.949 \mathrm{~ns}$ & $\begin{array}{l}12302.284 \\
\text { ns }\end{array}$ & $1.451^{*}$ \\
\hline$(\mathrm{A} \times \mathrm{B})$ & 10 & $0.722 * *$ & $\begin{array}{l}4.717 \\
* *\end{array}$ & $5.694 * *$ & $0.041 * *$ & $0.009 \mathrm{~ns}$ & $0.027 *$ & $3.507 \mathrm{~ns}$ & $0.919 *$ & $3.589 * *$ & $6.782 *$ & $\begin{array}{l}38522.125 \\
*\end{array}$ & $0.468 \mathrm{~ns}$ \\
\hline $\mathrm{Eb}$ & 34 & 0.028 & 0.007 & 0.178 & 0.001 & 0.010 & 0.009 & 2.600 & 0.394 & 0.301 & 2.587 & 17239.504 & 0.479 \\
\hline C.V $(\%)$ & & 6.32 & 1.50 & 5.24 & 6.53 & 23.47 & 8.31 & 4.68 & 1.69 & 4.72 & 1.73 & 17.91 & 9.57 \\
\hline
\end{tabular}

ns, not signiticant and **and* significantly on probability level of 1 and $5 \%$, respectively.

Table 4. Mean comparisons of studied characteristics of Rice (Oryza Sativa L. Nade Variety) seeds under duraation and concatratin of osmo-priming solutions.

\begin{tabular}{|c|c|c|c|c|c|c|c|c|c|c|c|c|}
\hline Treatment & $\begin{array}{c}\text { Primary } \\
\text { root } \\
\text { length } \\
(\mathrm{mm})\end{array}$ & $\begin{array}{c}\text { Primary } \\
\text { shoot } \\
(\mathrm{mm}) \\
\text { length }\end{array}$ & $\begin{array}{c}\text { Primary } \\
\text { seedling } \\
\text { length } \\
(\mathrm{mm})\end{array}$ & $\begin{array}{c}\text { Primary } \\
\text { root/ } \\
\text { primary } \\
\text { shoot } \\
\text { length } \\
\text { proportion } \\
(\mathrm{R} / \mathrm{S})\end{array}$ & $\begin{array}{c}\text { Primary } \\
\text { root/ } \\
\text { primary } \\
\text { shoot } \\
\text { fresh } \\
\text { weight } \\
\text { proportion } \\
(\mathrm{R} / \mathrm{S})\end{array}$ & $\begin{array}{c}\text { Primary } \\
\text { root/ } \\
\text { primary } \\
\text { shoot dry } \\
\text { weight } \\
\text { proportion } \\
(\mathrm{R} / \mathrm{S})\end{array}$ & $\begin{array}{c}\text { Normal } \\
\text { seedlings } \\
\text { number }\end{array}$ & $\begin{array}{c}\text { Abnormal } \\
\text { seedlings } \\
\text { number }\end{array}$ & $\begin{array}{c}\text { Germination } \\
\text { rate }\end{array}$ & $\begin{array}{c}\text { Germination } \\
\text { percent }\end{array}$ & $\begin{array}{l}\text { Vigor } 1 \\
\text { index }\end{array}$ & $\begin{array}{l}\text { Vigor } 2 \\
\text { index }\end{array}$ \\
\hline $\mathrm{T} 4$ & b 2.311 & b 5.300 & b 7.611 & c 0.432 & a 0.426 & a 1.167 & b 34 & b 36.78 & c 9.80 & b 92.08 & b 700.4 & c 6.632 \\
\hline $\mathrm{T} 8$ & a 3.267 & a 6.300 & a 9.172 & a 0.532 & a 0.440 & a 1.129 & a 35.61 & a 37.33 & b 12.14 & a 93.33 & a 818.7 & b 7.249 \\
\hline T12 & b 2.339 & c 5.033 & b 7.378 & b 0.473 & a 0.407 & a 1.56 & b 33.78 & ab 37.11 & a 12.87 & ab 92.78 & b 680.2 & a 7.804 \\
\hline PEG $5 \%$ & $\begin{array}{c}b c \\
2.678\end{array}$ & c 5.033 & a 7.722 & a 0.561 & a 0.396 & ab 1.166 & a 34.33 & a 37 & b 11.70 & a 92.50 & a 706.7 & a 7.413 \\
\hline PEG $10 \%$ & d 2.467 & a 5.700 & a 8.167 & d 0.432 & b 0.365 & ab 1.138 & a 34 & a 37.22 & c 10.76 & a 93.06 & a 759.4 & a 7.554 \\
\hline KNO3 $1 \%$ & $\begin{array}{c}\text { bcd } \\
2.600\end{array}$ & $\begin{array}{c}\mathrm{ab} \\
5.633\end{array}$ & a 8.011 & cd 0.456 & ab 0.456 & a 1.225 & a 34.22 & a 36.78 & c 10.87 & a 92.22 & a 740 & a 7.458 \\
\hline KNO3 2\% & $\begin{array}{c}\mathrm{cd} \\
2.500\end{array}$ & a 5.667 & a 8.167 & d 0.434 & ab 0.389 & b 1.095 & a 34.89 & a 37.11 & b 11.61 & a 92.78 & a 758.5 & ab 7.089 \\
\hline $\mathrm{KCl} 2 \%$ & a 2.900 & b 5.567 & a 8.156 & b 0.511 & ab 0.415 & ab 1.127 & a 35 & a 37.33 & a 12.41 & a 93.06 & a 671 & a 7.382 \\
\hline $\mathrm{KCl} 4 \%$ & b 2.689 & a 5.677 & a 8.100 & bc 0.481 & a 0.505 & ab 1.153 & a 34.33 & a 37 & a 12.27 & a 92.78 & a 763 & b 6.473 \\
\hline
\end{tabular}

*: In each column and each group cares with same letter had no significant diffrences in probability level of $5 \%$ based on Duncan multiplerange test. 
Table 5. Analyzse of variance of (Mean Square) studid characteristics under in Osmo-priming solutions concentration and duration and treatments of Cucumber (Cucumis Sativus L. P.S Variety) seeds

\begin{tabular}{|c|c|c|c|c|c|c|c|c|c|c|c|c|}
\hline S.O.V & $\mathrm{df}$ & $\begin{array}{c}\text { Primary } \\
\text { root } \\
\text { length }\end{array}$ & $\begin{array}{c}\text { Primary } \\
\text { shoot } \\
\text { length }\end{array}$ & $\begin{array}{c}\text { Primary } \\
\text { root/ } \\
\text { primary } \\
\text { shoot } \\
\text { length } \\
\text { proportion } \\
(\mathrm{R} / \mathrm{S})\end{array}$ & $\begin{array}{c}\text { Primary } \\
\text { root/ } \\
\text { primary } \\
\text { shoot fresh } \\
\text { weight } \\
\text { proportion } \\
(\mathrm{R} / \mathrm{S})\end{array}$ & $\begin{array}{c}\text { Primary } \\
\text { root/ } \\
\text { primary } \\
\text { shoot dry } \\
\text { weight } \\
\text { proportion } \\
(\mathrm{R} / \mathrm{S})\end{array}$ & $\begin{array}{c}\text { Normal } \\
\text { seedlings } \\
\text { number }\end{array}$ & $\begin{array}{c}\text { Germination } \\
\text { rate }\end{array}$ & $\begin{array}{c}\text { Germination } \\
\text { percent }\end{array}$ & $\begin{array}{c}\text { Primary } \\
\text { root fresh } \\
\text { weight }\end{array}$ & $\begin{array}{c}\text { Primary } \\
\text { shoot } \\
\text { fresh } \\
\text { weight }\end{array}$ & $\begin{array}{c}\text { Primary } \\
\text { seddling } \\
\text { fresh } \\
\text { weight }\end{array}$ \\
\hline Replication & 2 & $0.412 \mathrm{~ns}$ & $0.634 \mathrm{~ns}$ & $0.017 \mathrm{~ns}$ & $0.005 \mathrm{~ns}$ & $0.101 \mathrm{~ns}$ & $1.685 \mathrm{~ns}$ & $15.407 \mathrm{~ns}$ & $15.407 \mathrm{~ns}$ & $0.000 \mathrm{~ns}$ & $0.001 \mathrm{~ns}$ & $0.002 \mathrm{~ns}$ \\
\hline $\begin{array}{c}\text { DurAation } \\
\text { (A) }\end{array}$ & 2 & $5.871 *$ & $\begin{array}{c}12.869 \\
* *\end{array}$ & $0.215 *$ & $0.086^{* *}$ & $0.407 *$ & $4.741 *$ & $61.630 * *$ & $61.630 * *$ & $0.002 \mathrm{~ns}$ & $0.014 * *$ & $0.026 * *$ \\
\hline $\begin{array}{c}\text { Osmo-priming } \\
\text { (B) }\end{array}$ & 5 & $0.884 * *$ & $0.550 *$ & $0.035 *$ & $0.006 *$ & $0.344 * *$ & $0.507 \mathrm{~ns}$ & $26.607 * *$ & 26.607 ** & $0.001 *$ & $0.001 *$ & $0.003 *$ \\
\hline$(A \times B)$ & 10 & $1.331 *$ & $1.754 *$ & $0.132 *$ & $0.009 * *$ & $0.202 *$ & $0.785 *$ & $16.830 *$ & $16.830 *$ & $0.001 * *$ & $0.001 * *$ & $0.003 * *$ \\
\hline $\mathrm{Eb}$ & 34 & 1.196 & 1.237 & 0.070 & 0.008 & 0.078 & 0.920 & 6.309 & 6.309 & 0.001 & 0.001 & 0.003 \\
\hline C.V (\%) & & 15.46 & 21.51 & 18.73 & 12.46 & 20.66 & 3.98 & 2.59 & 2.59 & 20.60 & 20.55 & 19.72 \\
\hline
\end{tabular}

ns, not signiticant and **and* significantly on probability level of 1 and $5 \%$, respectively.

Table 6. Mean comparisons of studied characteristics of Cucumber (Cucumis Sativus L. P.S Variety) seeds under duraation and concatratin of osmo-priming solutions

\begin{tabular}{|c|c|c|c|c|c|c|c|c|c|c|c|}
\hline Treatment & $\begin{array}{c}\text { Primary } \\
\text { root } \\
\text { length } \\
(\mathrm{mm})\end{array}$ & $\begin{array}{c}\text { Primary } \\
\text { shoot } \\
\text { length } \\
(\mathrm{mm})\end{array}$ & $\begin{array}{c}\text { Primary } \\
\text { root/ } \\
\text { primary } \\
\text { shoot } \\
\text { length } \\
\text { proportion } \\
(\mathrm{R} / \mathrm{S})\end{array}$ & $\begin{array}{c}\text { Primary } \\
\text { root/ } \\
\text { primary } \\
\text { shoot fresh } \\
\text { weight } \\
\text { proportion } \\
(\mathrm{R} / \mathrm{S})\end{array}$ & $\begin{array}{c}\text { Primary root/ } \\
\text { primary } \\
\text { shoot dry } \\
\text { weight } \\
\text { proportion } \\
(\mathrm{R} / \mathrm{S})\end{array}$ & $\begin{array}{c}\text { Normal } \\
\text { seedlings } \\
\text { number }\end{array}$ & $\begin{array}{l}\text { Germination } \\
\text { rate }\end{array}$ & $\begin{array}{c}\text { Germination } \\
\text { percent }\end{array}$ & $\begin{array}{c}\text { Primary } \\
\text { root fresh } \\
\text { weight (gr) }\end{array}$ & $\begin{array}{c}\text { Primary } \\
\text { shoot fresh } \\
\text { weight (gr) }\end{array}$ & $\begin{array}{c}\text { Primary } \\
\text { seddling } \\
\text { fresh weight } \\
\text { (gr) }\end{array}$ \\
\hline T6 & $5.920 \mathrm{~b}$ & $2.990 \mathrm{~b}$ & $1.970 \mathrm{a}$ & $0.810 \mathrm{~b}$ & $0.130 \mathrm{~b}$ & $25 \mathrm{a}$ & $6.80 \mathrm{~b}$ & $100 \mathrm{a}$ & $0.089 \mathrm{a}$ & $0.109 \mathrm{~b}$ & $0.198 \mathrm{~b}$ \\
\hline $\mathrm{T} 12$ & $7.100 \mathrm{a}$ & $4.110 \mathrm{a}$ & $1.720 \mathrm{~b}$ & $0.740 \mathrm{c}$ & $0.850 \mathrm{a}$ & $25 \mathrm{a}$ & $9.05 \mathrm{a}$ & $100 \mathrm{a}$ & $0.138 \mathrm{a}$ & $0.138 \mathrm{a}$ & $0.241 \mathrm{a}$ \\
\hline $\mathrm{T} 18$ & $6.310 \mathrm{~b}$ & $3.790 \mathrm{a}$ & $1.660 \mathrm{~b}$ & $0.920 \mathrm{a}$ & $0.850 \mathrm{a}$ & $23 \mathrm{~b}$ & $6 \mathrm{~b}$ & $92 \mathrm{~b}$ & $0.106 \mathrm{a}$ & $0.115 \mathrm{~b}$ & $0.221 \mathrm{ab}$ \\
\hline PEG $5 \%$ & $7.930 \mathrm{~b}$ & $6.460 \mathrm{a}$ & $1.220 \mathrm{c}$ & $0.790 \mathrm{~b}$ & $0.460 \mathrm{c}$ & $24 \mathrm{a}$ & $7.40 \mathrm{a}$ & $96 \mathrm{~b}$ & $0.168 \mathrm{a}$ & $0.212 \mathrm{a}$ & $0.380 \mathrm{a}$ \\
\hline PEG $10 \%$ & $6.550 \mathrm{c}$ & $4.990 \mathrm{~b}$ & $1.310 \mathrm{c}$ & $0.730 \mathrm{~b}$ & $0.850 \mathrm{~b}$ & $24 \mathrm{a}$ & $5.95 \mathrm{a}$ & $96 \mathrm{~b}$ & $0.109 \mathrm{a}$ & $0.149 \mathrm{~b}$ & $0.258 \mathrm{~b}$ \\
\hline KNO3 1\% & $8.160 \mathrm{~b}$ & $4.230 \mathrm{~b}$ & $1.920 \mathrm{a}$ & $0.890 \mathrm{a}$ & $0.450 \mathrm{c}$ & $24 \mathrm{a}$ & $0.20 \mathrm{~b}$ & $96 \mathrm{~b}$ & $0.123 \mathrm{~b}$ & $0.137 \mathrm{~b}$ & $0.260 \mathrm{~b}$ \\
\hline KNO3 2\% & $7.190 \mathrm{bc}$ & $4.440 \mathrm{~b}$ & $1.620 \mathrm{~b}$ & $0.920 \mathrm{a}$ & $1.50 \mathrm{a}$ & $25 \mathrm{a}$ & $6.15 \mathrm{a}$ & $96 \mathrm{~b}$ & $0.120 \mathrm{~b}$ & $0.130 \mathrm{~b}$ & $0.250 \mathrm{~b}$ \\
\hline $\mathrm{KCl} 2 \%$ & $6.200 \mathrm{c}$ & $4.600 \mathrm{~b}$ & $1.340 \mathrm{c}$ & $0.790 \mathrm{~b}$ & $0.720 \mathrm{bc}$ & $25 \mathrm{a}$ & $6.20 \mathrm{a}$ & $100 \mathrm{a}$ & $0.116 \mathrm{~b}$ & $0.146 \mathrm{~b}$ & $0.262 \mathrm{~b}$ \\
\hline $\mathrm{KCl} 4 \%$ & $9.370 \mathrm{a}$ & $4.420 \mathrm{~b}$ & $2.110 \mathrm{a}$ & $0.940 \mathrm{a}$ & $0.460 \mathrm{c}$ & $24 \mathrm{a}$ & $7.05 \mathrm{a}$ & $100 \mathrm{a}$ & $0.130 \mathrm{~b}$ & $0.138 \mathrm{~b}$ & $0.268 \mathrm{~b}$ \\
\hline
\end{tabular}

*: In each column and each group cares with same letter had no significant diffrences in probability level of 5\% based on Duncan multiplerange test 


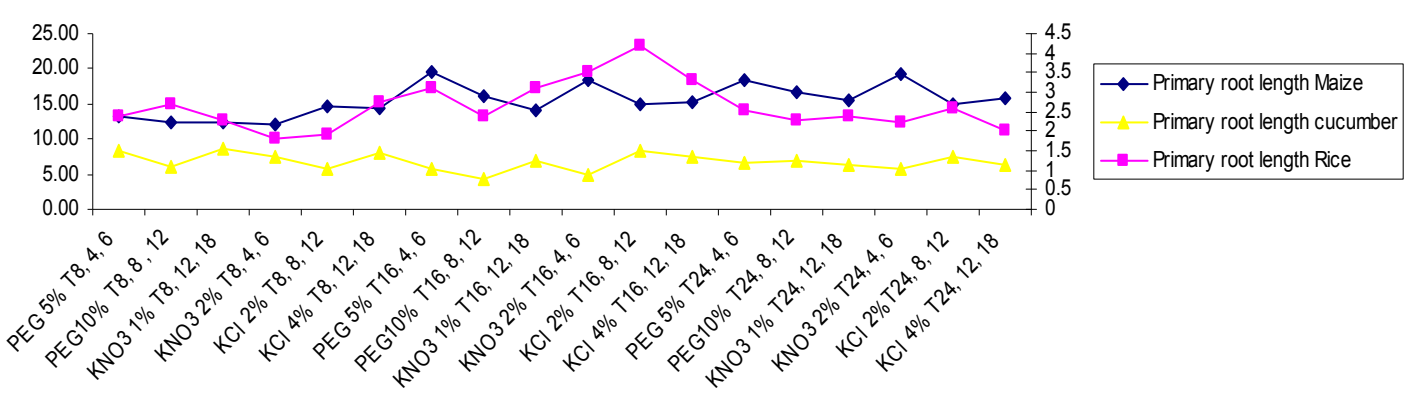

Figure 1. The mean comparisons of interaction effect of different time and priming levels on the primary roots length of Maize, Rice and Cucumber

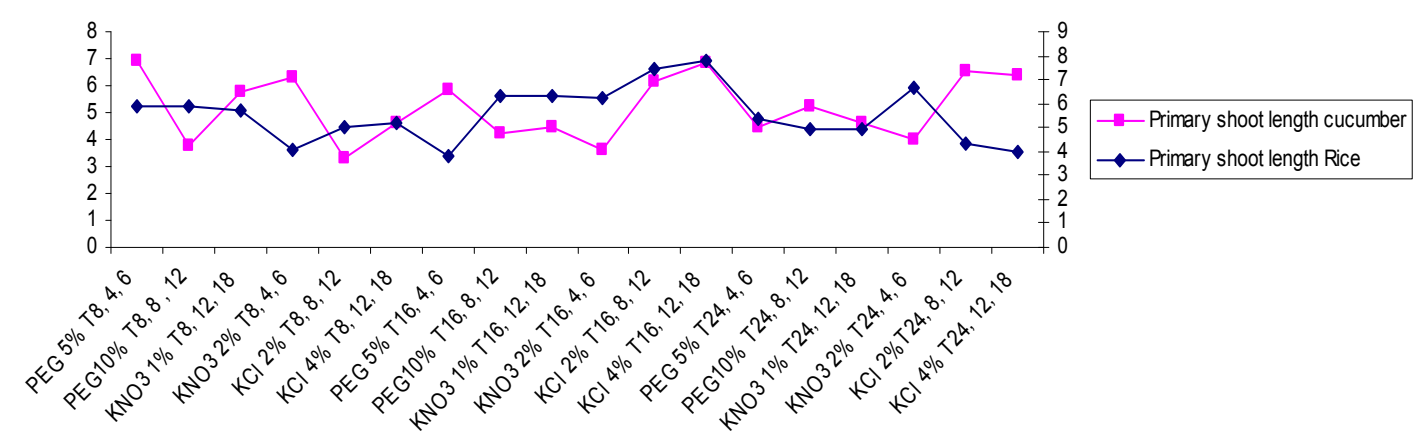

Figure 2. The mean comparisons of interaction effect of different time and priming levels on the primary shoots length of Rice and Cucumber

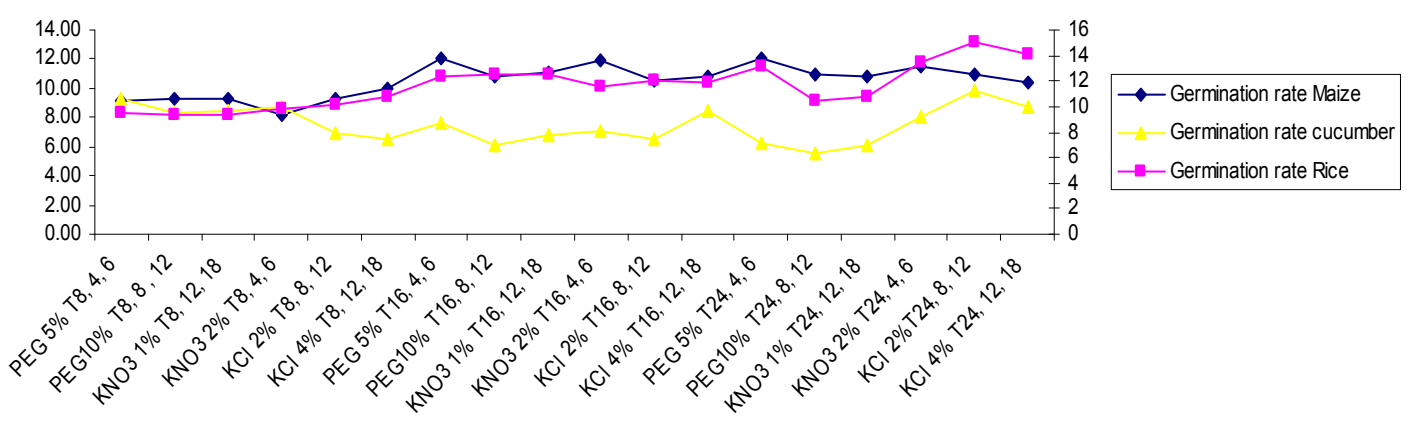

Figure 3. The mean comparisons of interaction effect of different time and priming levels on the germination rate of Maize, Rice and Cucumber 


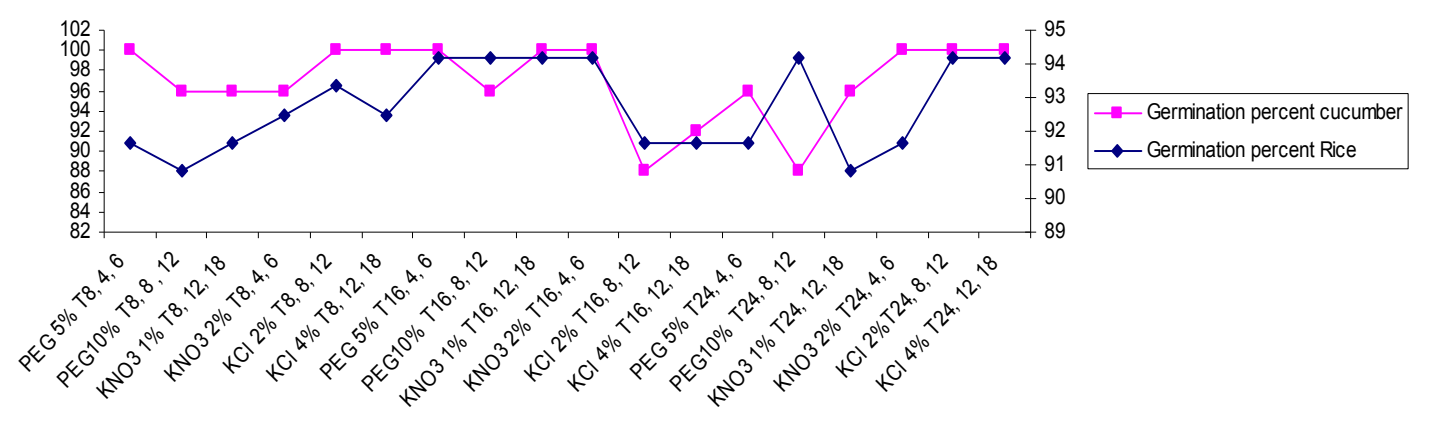

Figure 4. The mean comparisons of interaction effect of different time and priming levels on the germination percent of Rice and Cucumber

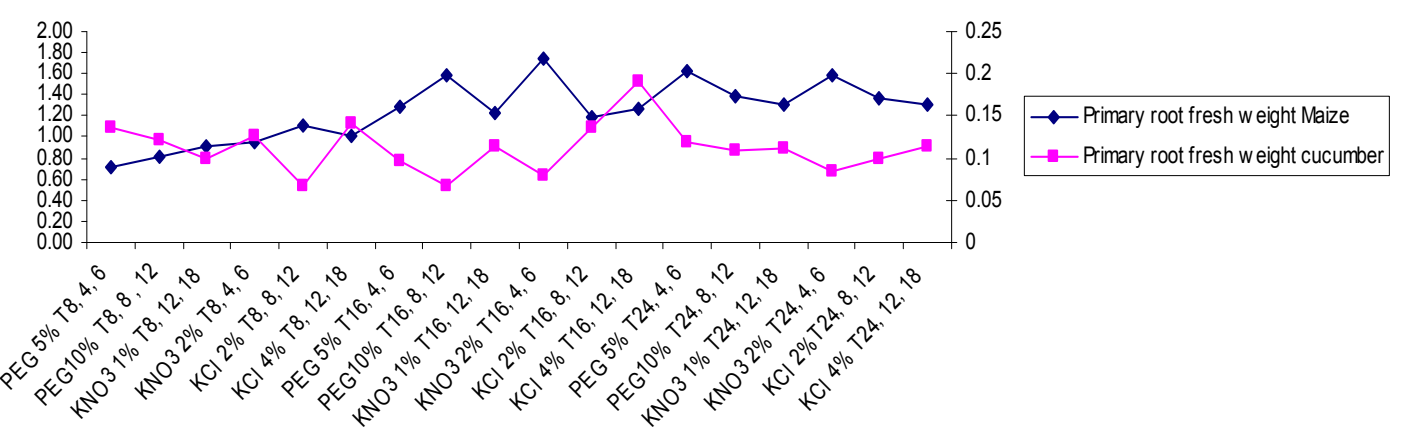

Figure 5. The mean conparisons of interaction effect of different time and priming levels on of Maize and Cucumber roots fresh weight

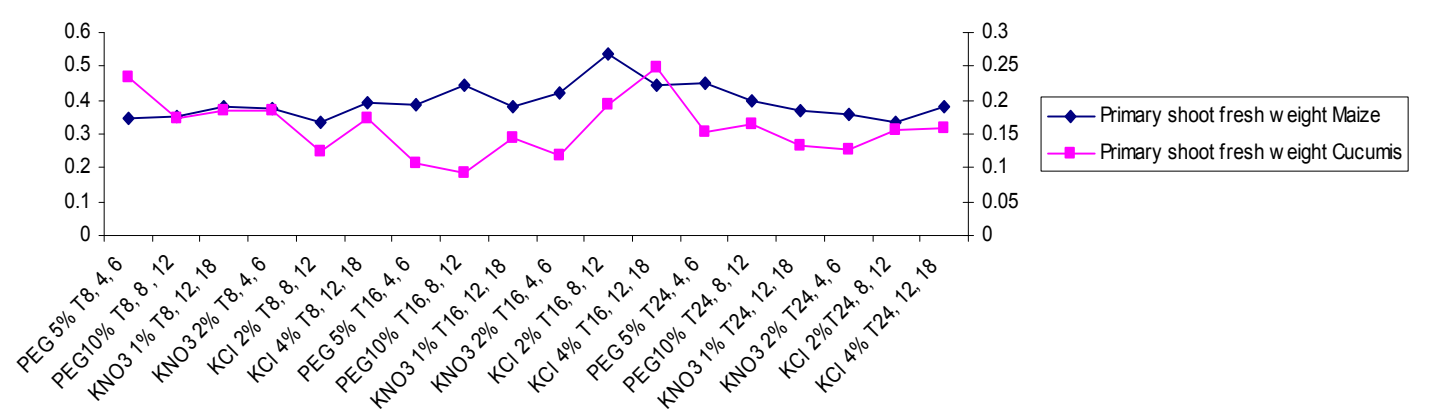

Figure 6. The mean conparisons of interaction effect of different time and priming levels on of Maize and Cucumber shoots fresh weight 


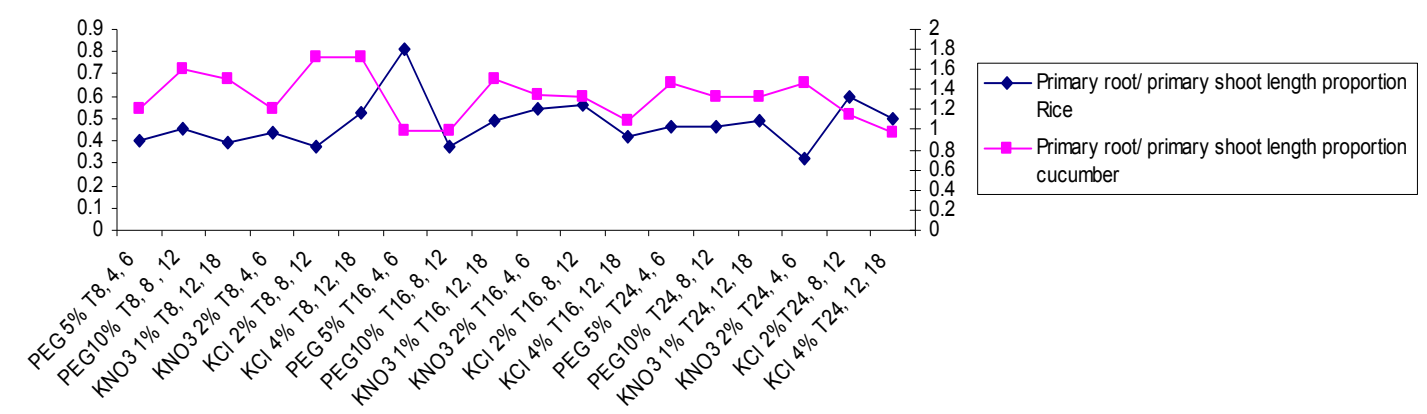

Figure 7. The mean conparisons interaction effect of different levels of time and priming on primary root/ primary shoot length proportion of Rice and Cucumber seedling

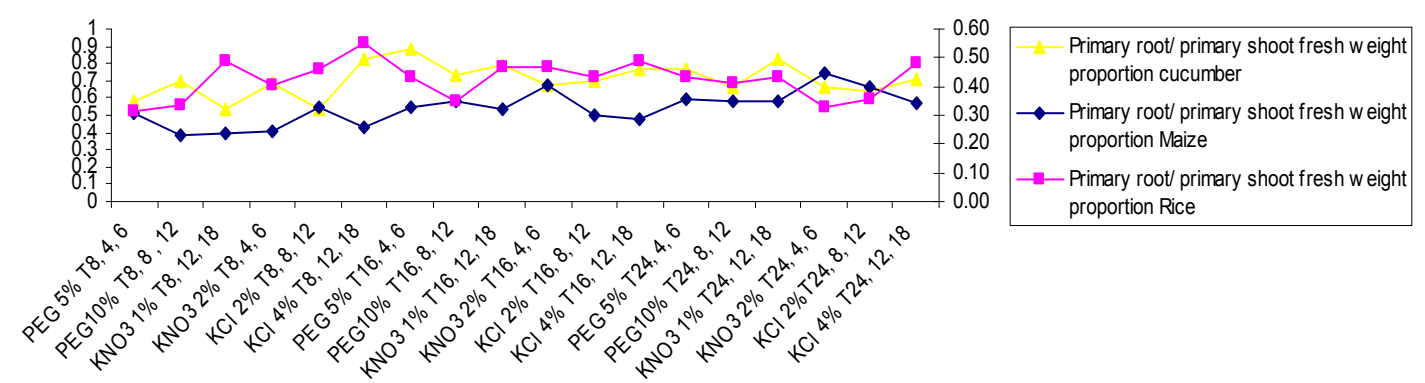

Figure 8 . The mean conparisons interaction effect of different levels of time and priming on primary root/ primary shoot ftresh weight proportion of Maiz, Rice and Cucumber seedling

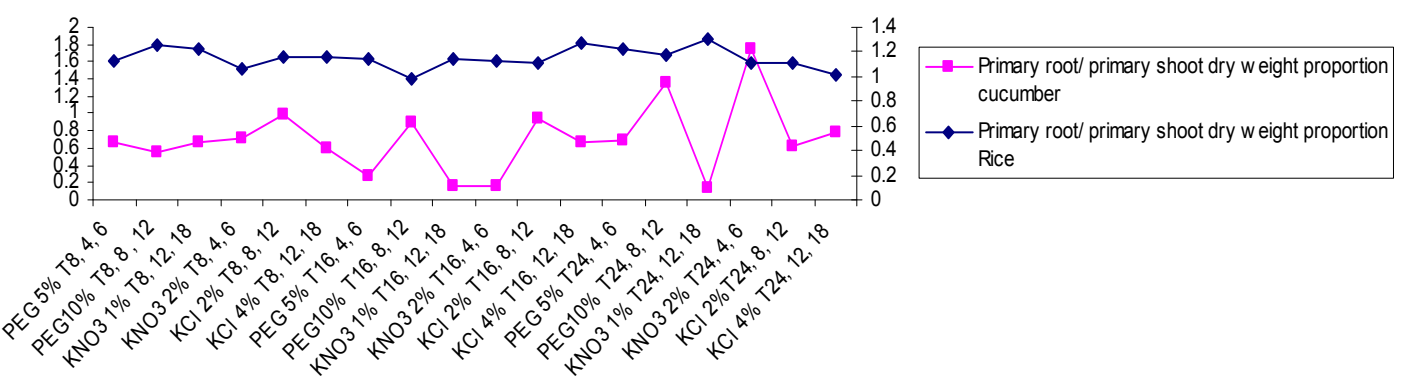

Figure 9. The mean conparisons interaction effect of different levels of time and priming on primary root/ primary shoot dry weight proportion of Rice and Cucumber seedling 


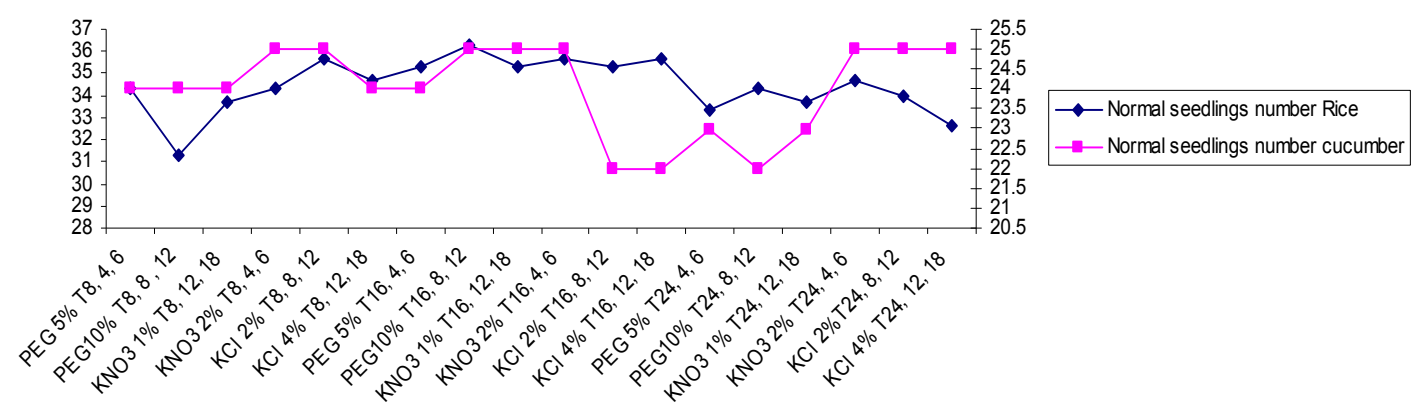

Figure 10. The mean conparisons interaction effect of different levels of time and priming on normal seedlings number of Rice and Cucumber seedling

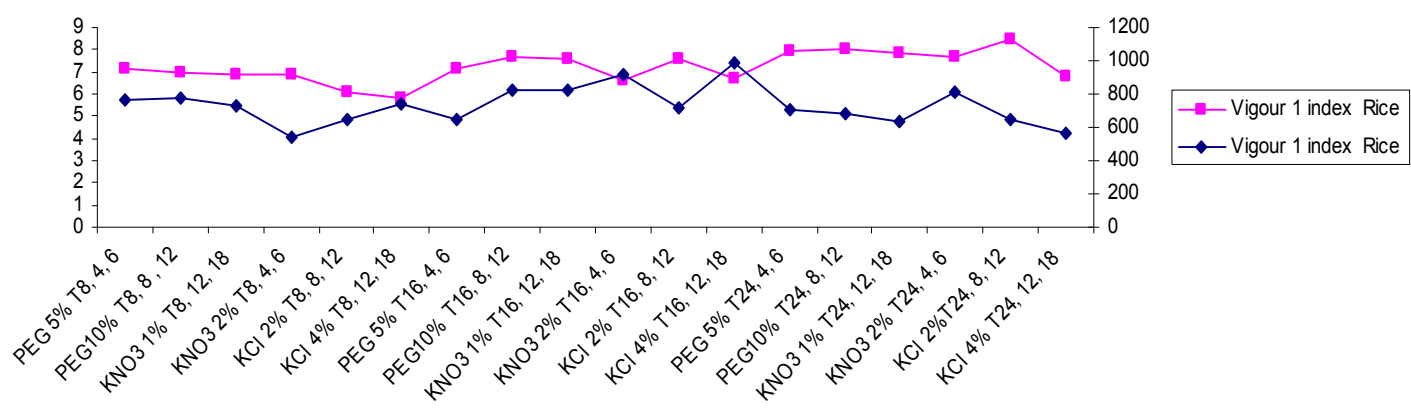

Figure 11. The mean conparisons interaction effect of different levels of time and priming on Vigour 1 index of Rice and Cucumber seedling 